\title{
Avitinib Maleate
}

National Cancer Institute

\section{Source}

National Cancer Institute. Avitinib Maleate. NCI Thesaurus. Code C118671.

The maleate salt form of avitinib, an orally available, irreversible, epidermal growth factor receptor (EGFR) mutant-selective inhibitor, with potential antineoplastic activity. Upon oral administration, avitinib covalently binds to and inhibits the activity of mutant forms of EGFR, including the drug-resistant T790M EGFR mutant, which prevents signaling mediated by mutant forms of EGFR. This may both induce cell death and inhibit tumor growth in EGFR-mutated tumor cells. EGFR, a receptor tyrosine kinase that is mutated in a variety of cancers, plays a key role in tumor cell proliferation and tumor vascularization. As this agent is selective towards mutant forms of EGFR, its toxicity profile may be reduced when compared to non-selective EGFR inhibitors, which also inhibit wild-type EGFR. 